\title{
تعقيب السيوطي على القاضي البيضاوي
}

ILHAM SYUKRI

Institut Agama Islam Negeri (IAIN) Bengkulu

\begin{abstract}
Abstrak : As-Suyuti adalah ulama besar yang hidup di abad ke-8 hijriah. Salah satu karyanya yang fenomenal dalam bidang tafsir adalah Hasyiah Tafsir Baidhawi. Di antara Faktor yang menyebabkan As-Suyuti mengkritik Al-Baidhawi adalah karena Al-Baidhawi banyak menukil pendapat Abu Hayyan dalam tafsirnya. Seperti yang kita ketahui Abu Hayyan dan Az-Zamakhsyari berasal dari dua madrasah yang berbeda. Komentar dan kritikan dalam suatu permasalahan bahasa dalam tafsir Al-Quran mengandung sisi positif dan negatif. Diantara sisi positifnya adalah bahwa para ulama tafsir saling melengkapi kekurangan satu sama lain dan ikut andil dalam memberikan penafsiran yang layak untuk Al-Quran. Al- Quran adalah firman Allah Swt yang mengandung mukjizat, diantara mukjizatnya adalah setiap kata-katanya mengandung makna yang banyak dan luas cakupannya walaupun secara zahirnya sama.
\end{abstract}

Kata kunci: Komentar, As-Suyuti.

\section{مقدمة}

الحمد لله رب العالمين الذي يحكم لا معقبّب لحكمه، سبحانك لا علم لنا إلا ما

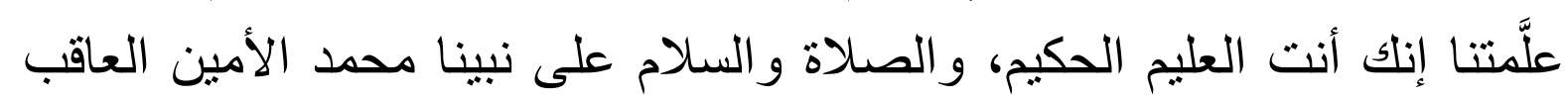

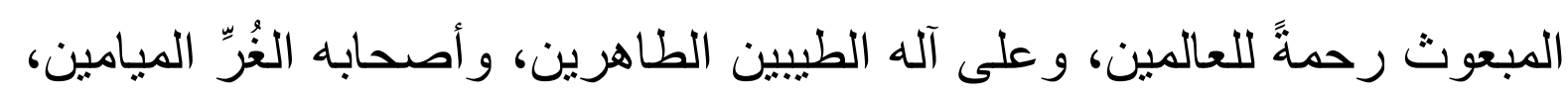
و التابعين لهم بإحسان إلى يوم الدين.

أما بعد.

فإن أشرف العلومِ و المعارف و أعلاها قدراً علمُ كتاب الله تعالى، فكل علوحِ

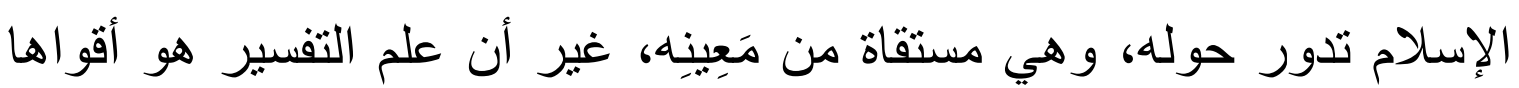
علاقة به، إذ به يَعْرِفُ المقصود من كلام رب العالمين، ولذلك تسابق علماء

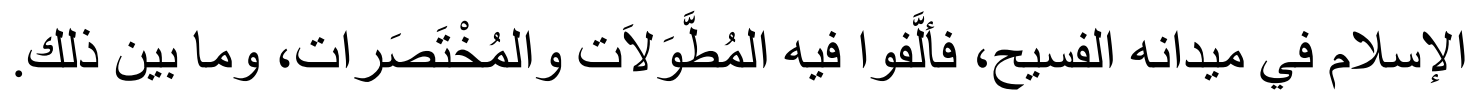

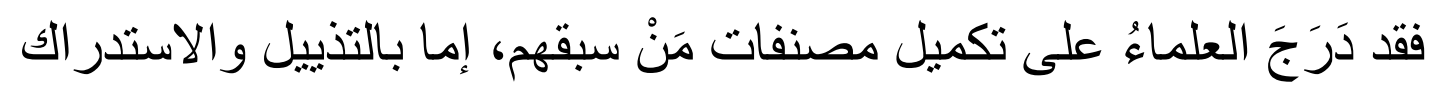
و التعقيب، وإما ببيان الأوهام ونحوها، على اختلاف مناهجهم في تدوين ذلك، 


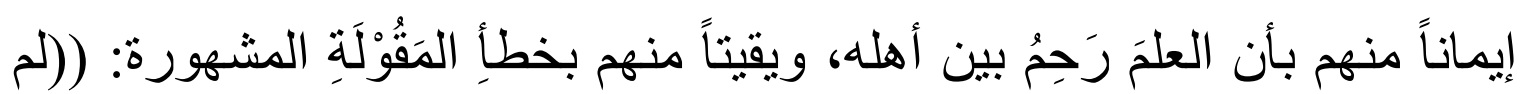

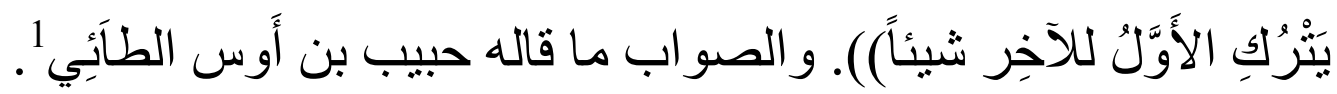

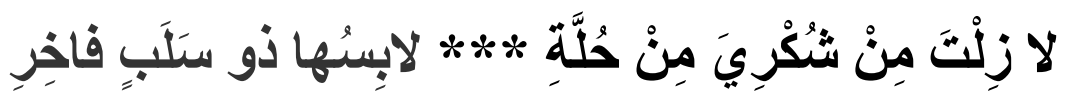

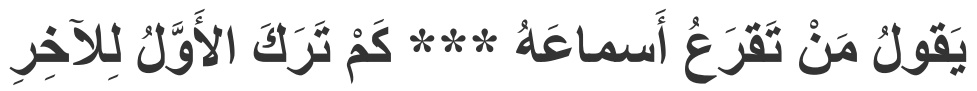

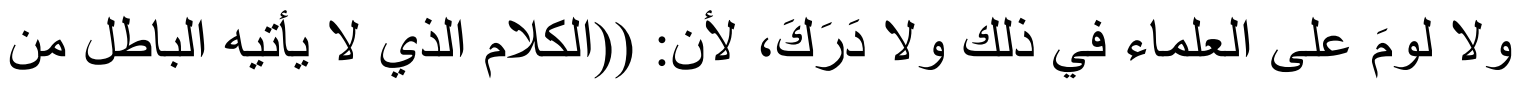

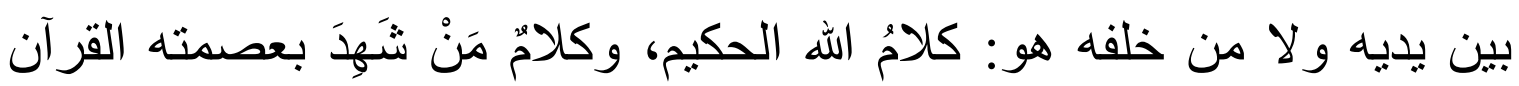

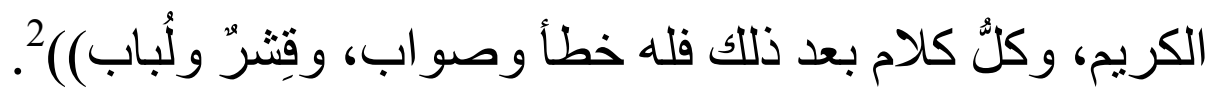

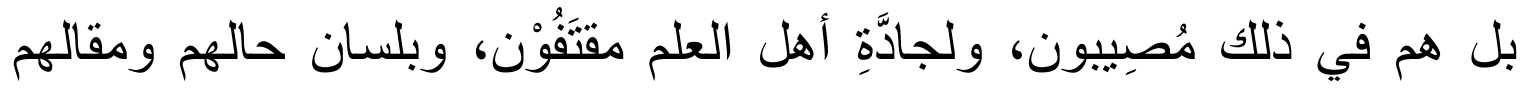

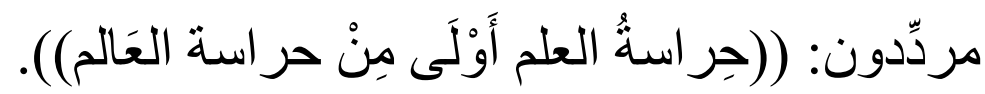
وكان من أبرز هؤلاء العلماء القاضي البيضاوي، والإمام الحافظ جلال الدين

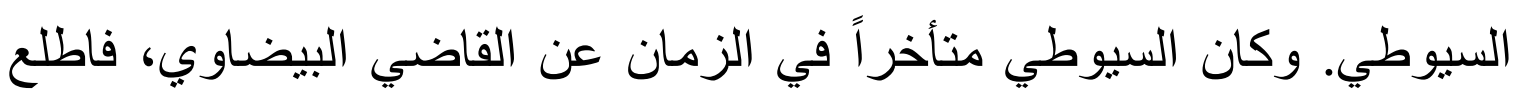

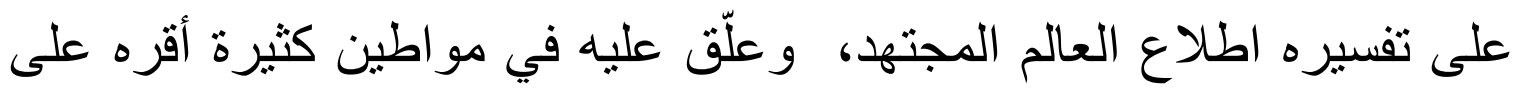

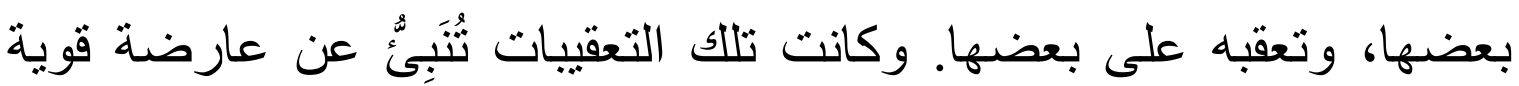

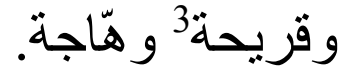 \\ بيان المفهوم اللغوى لمصطلح التعقيبات}

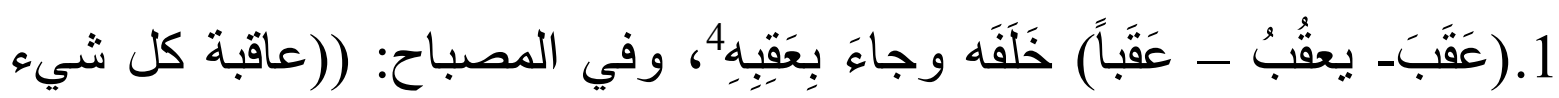

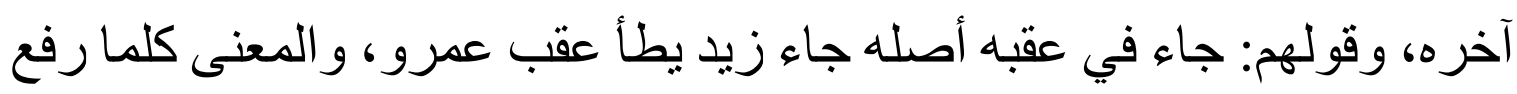
عمرو قدما وضع زيد قدمه مكانها، ثم كثر حتى قيل: جاء عقبه، ثم كثر حتى

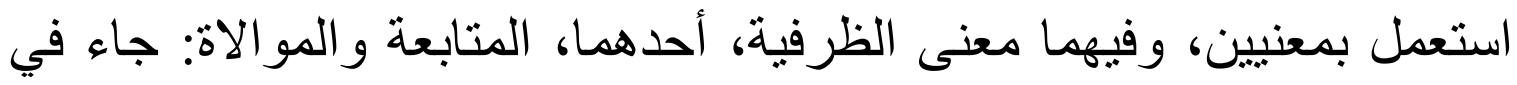
عقبه فمعناه في إثره، ومنه سمي المصطفى (ع) العاقب لأنه أعقب من كان قبله الأبله من الأنبياء، أي جاء بعدهم، الثاني، إدراك جزء ونه من المذكور معه، يقال: جاء 
في عقب رمضان، إذا جاء وقد بقي منه بقية، ويقال إذا برىء المريض وبقي شيء من المرض: هو في عقب المرض)(أ)

2. التعقيبات جمع تعقيب (لغير المصدر) تعقيب مصدر (عَقَّبَ على) و عَقَّبَه تعقيباً

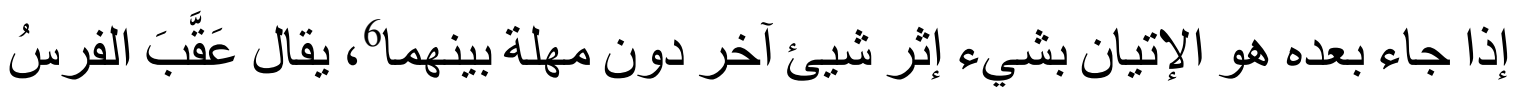

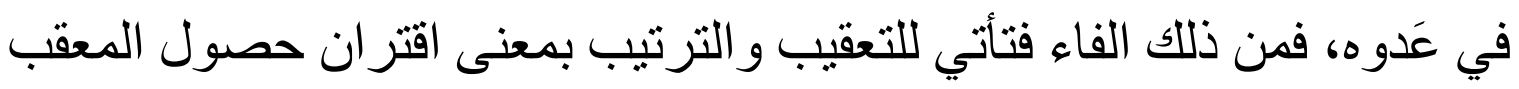
به للمعقب في الزمن مع الترتيب، وذلك هو الأصل فيها، كما قال الثوكاني في ((إرشاد الفحول)): ((فالفاء للتعقيب بإجماع أهل اللغة و إذا وردت لغير تعقيب

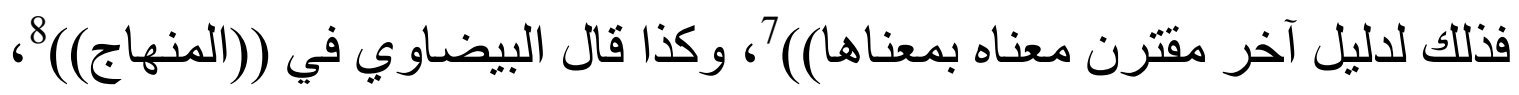
ومثال ذللك قوللك: (جاء زيد فمحمد) فالفاء هنا للتعقيب. 3. عَقَّبَ عليه: أي كر ورجع في الأمر كما قال ابن الأثير: (التعقيب هو أن تعمل

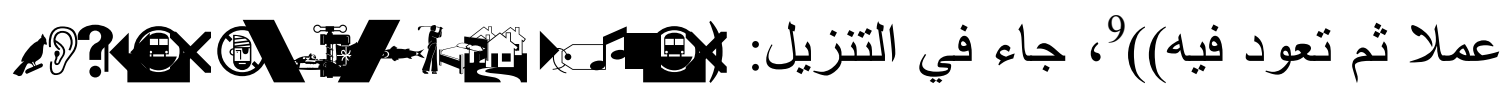

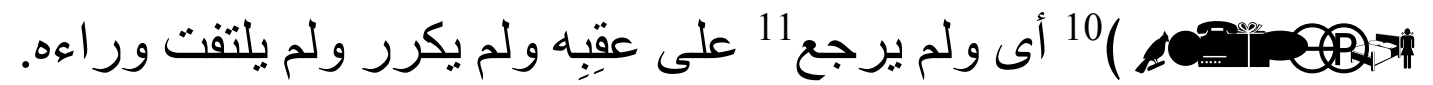

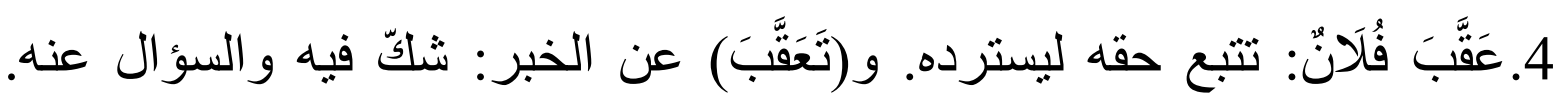

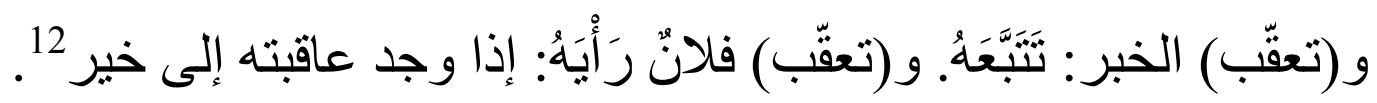

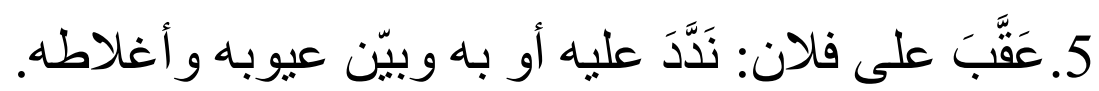

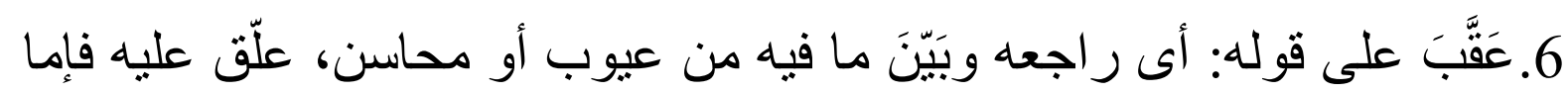

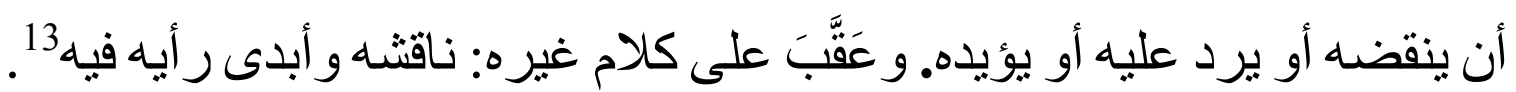

5 محمد بن على الفيومي المقرئ ((المصباح المنير)) ص 159، كتاب العين: العين مع القاف وما يثلثهما، مكتبة لبنان. 1987م

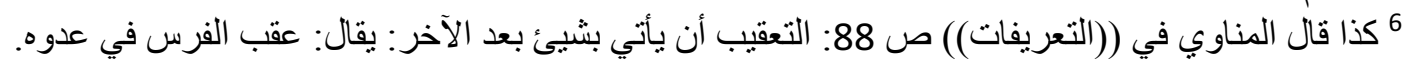

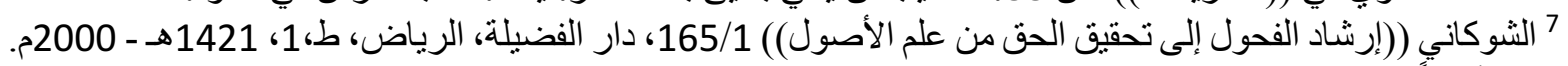

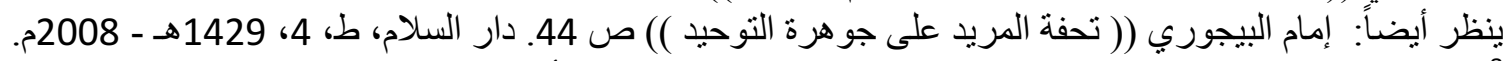

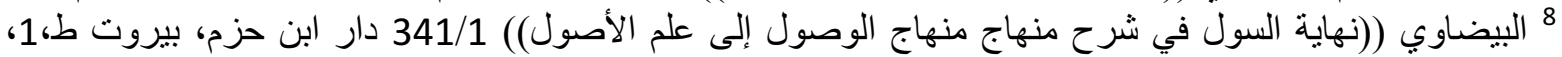

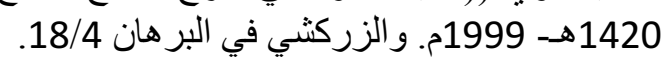

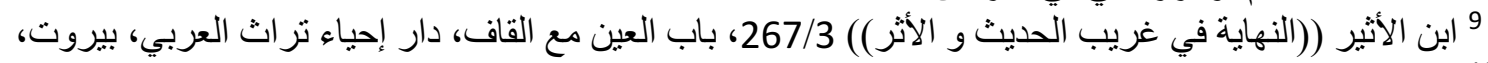

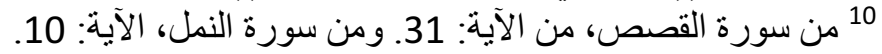
11 ينظر : ((جامع البيان عن تأويل آي القرآن)) تفسير سورة النئ النمل، الآية: 10. 10. 15/18.

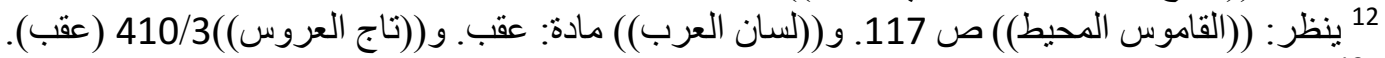

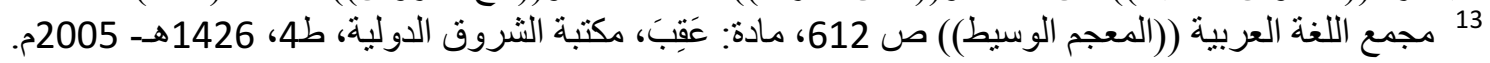


7. عَقَّبَ القاضي على حكم ستَلَهِ: أى أبطله، حكم بغيره ومنه قوله تعالى:

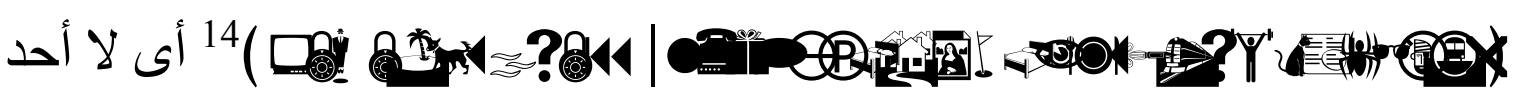

$$
\text { يتُعبه أي يكر ويبحث عن فعله وقضائه و أحكامه. }
$$

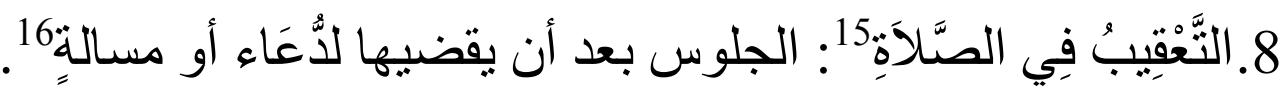

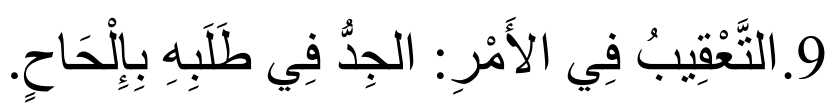

وجمع الفيروز آبادي بعض معاني التعقيب فقال: (والتعقيب اصفِرِ ارُ ثَمَرَةِ

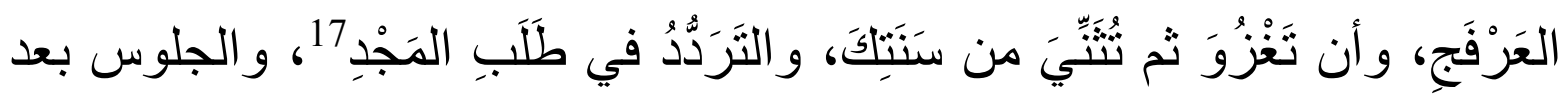

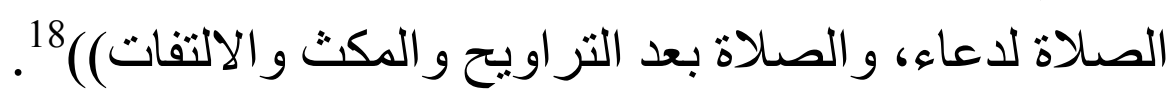

ومما سبق يتضح أن كلمة (تعقبب) 19، تعنى الثيء يأتي بعد الآخر، الرجوع في الأمر، الالتفات، مناقنشة أو مر اجعة الثيئ تأييداً أو نقداً.

بيان المفهوم الاصطلاحى لمصطلح التعقيبات والمقصود من تعقيبات العلامة السيوطي في حاثيته على القاضي البيضاوي في تفسيره.

و أقصد بـ (المفهوم الاصطلاحى) أى معناه المقصود في هذا البحث بالتحديد،

إن المعنى الاصطلاحى للتعقيب مستخدم في التراث الإسلامى بمعنى النقد و الرد أو النفى، فدائماً ما يدور هذا اللفظ على ألسنة العلماء 20 حيث يقولون: ((تَعَقَّبَ فلان فلاناً) أي رد كلامه ولم يرتضه، ولكن في الرسالة سأتوسع في معناه لأدخل ما أضافه السيوطي على أراء البيضاوي - مع إقرار بها - بطريق الإستدر اكات لأن

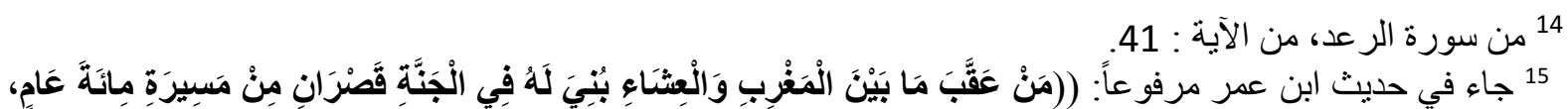

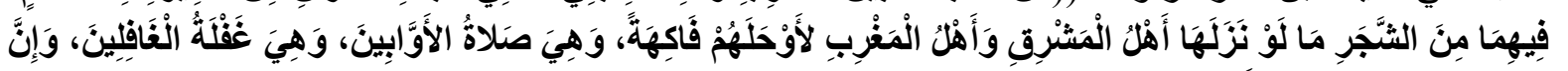

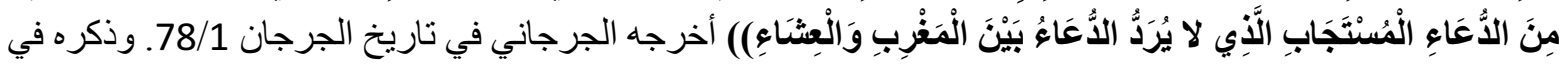
كنز العمال 161/7.

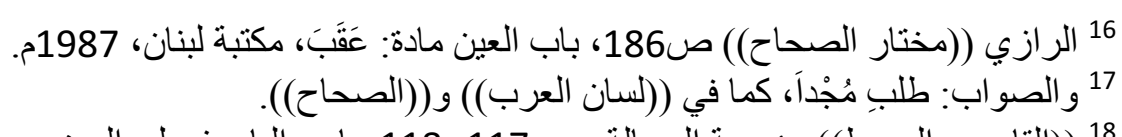

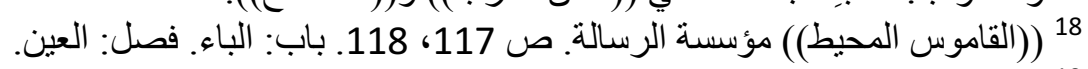

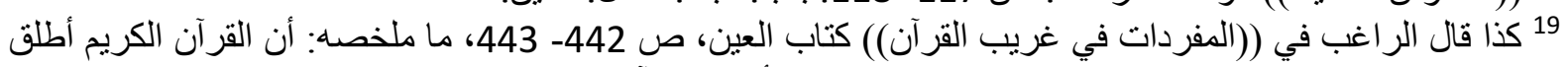

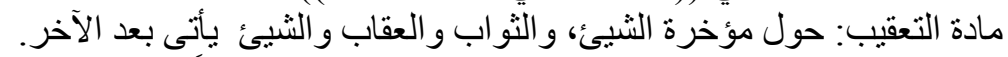

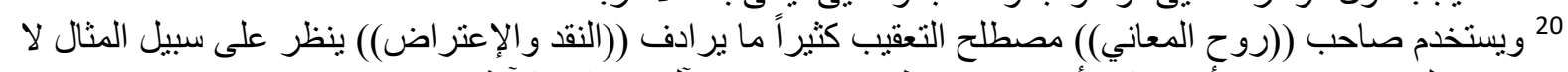

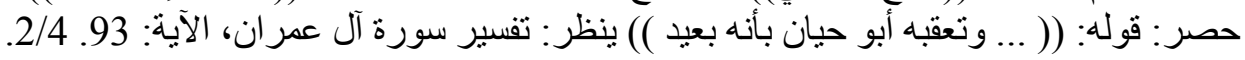


التعقبب أيضاً يطلق على الاستدر الك على الكلام بالتقرير و الإثبات أو النفي و النقد

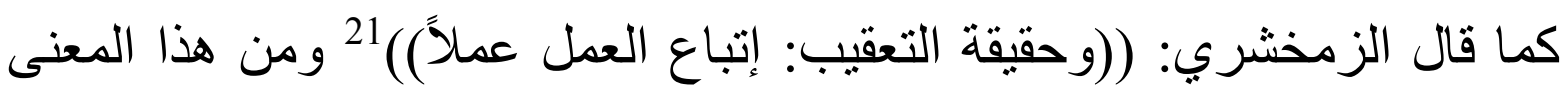
انطلقت هذه الفكرة. و الله أعلم.

•

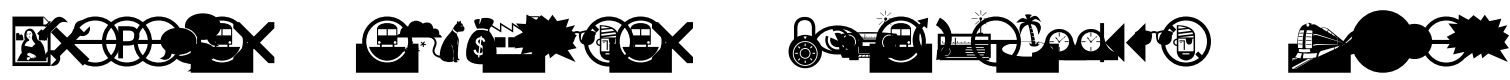

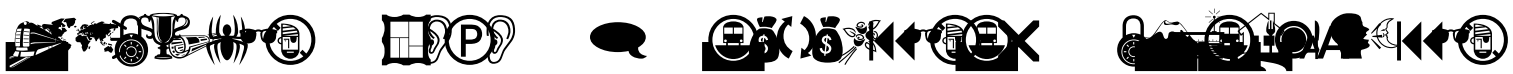

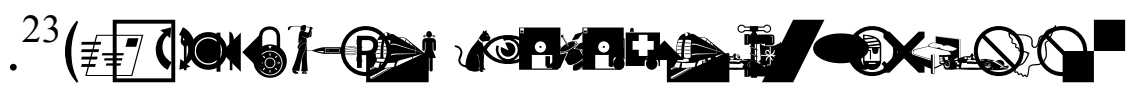
1. تفسير موجز للنص الكريم

\section{قوله}

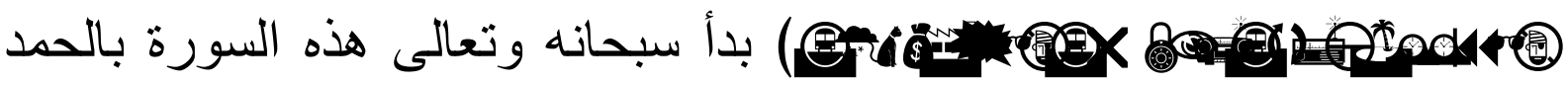
لنفسه تعليماً لعباده أن يحْمَدوه بهذه الصيغة الجامعة لصنوف التعظيم و التبجيل

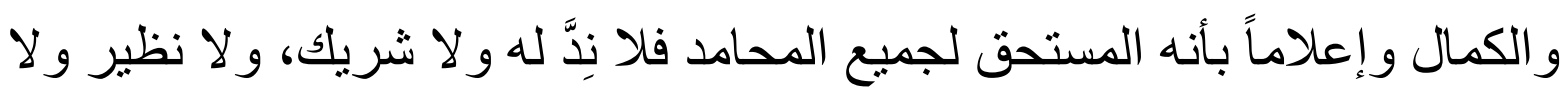

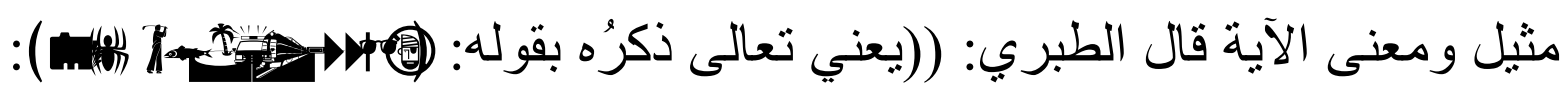

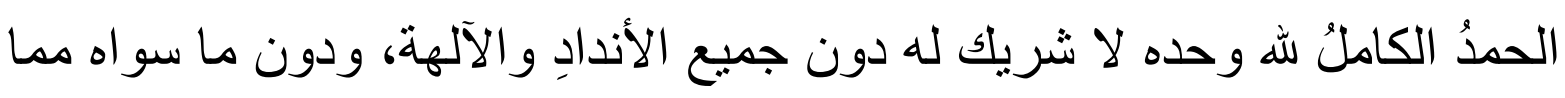
تعبده كَفَرةُ خلْقه من الأوثان والأصنام)(24) X

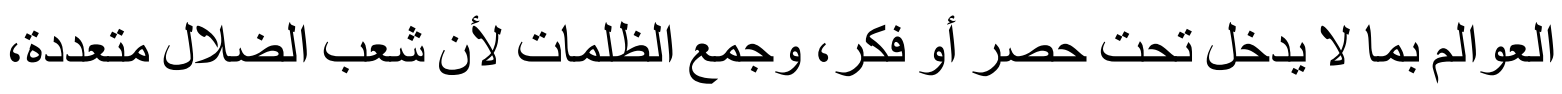

$$
21 \text { الزمخشري ((الفائق في غريب الحديث)) 913/4، دار الفكر بيروت، 1414هـ - 1493 1993م. }
$$

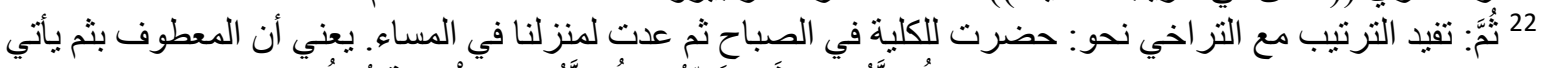

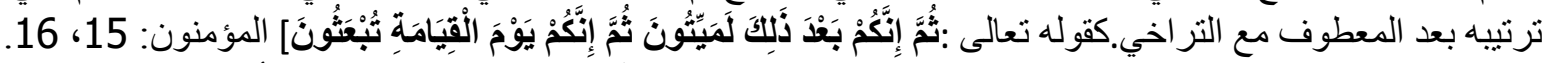

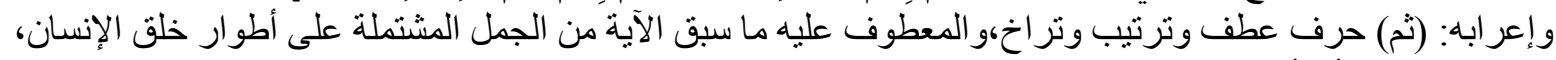

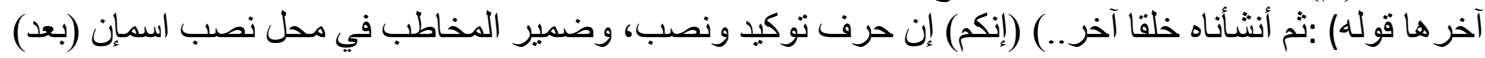

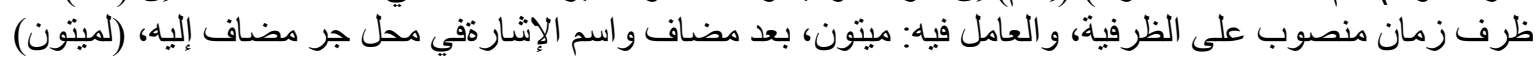

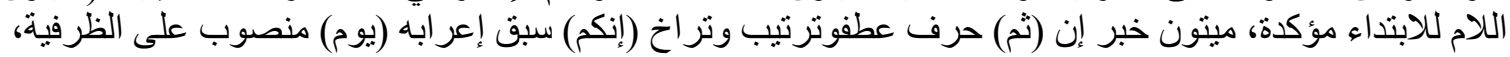

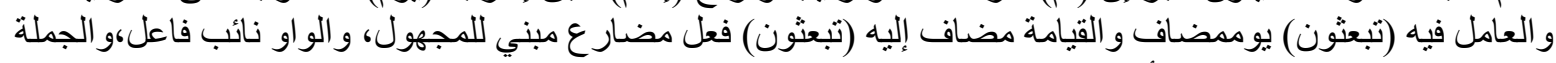

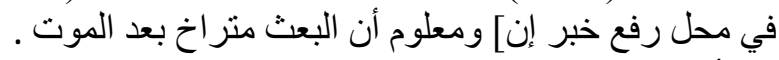

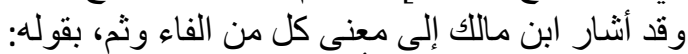

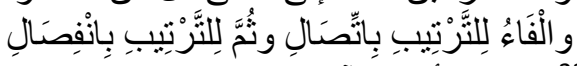

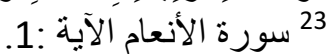
24 ابن جرير الطبري (الانعام :1422 
ومسالكه متنوعة، و أفرد النور لأن مصدره واحد هو الرحمن منوّر الأكوان قال

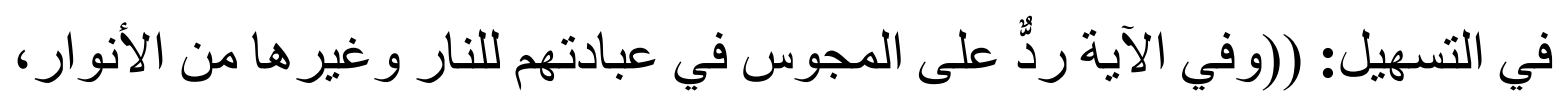

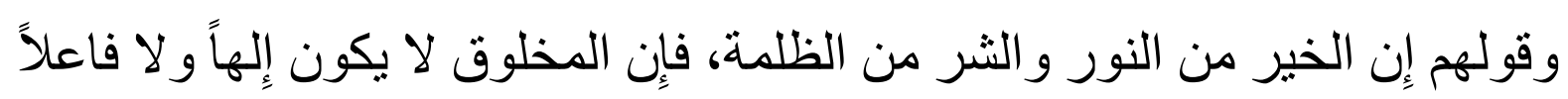

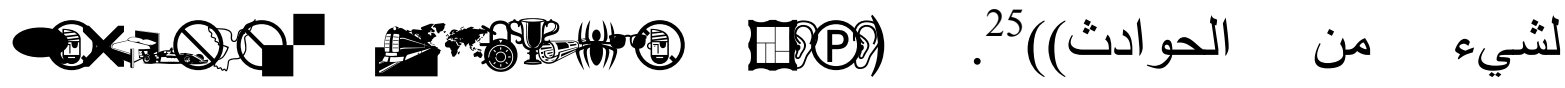

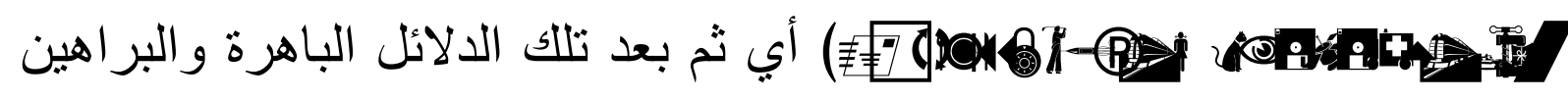

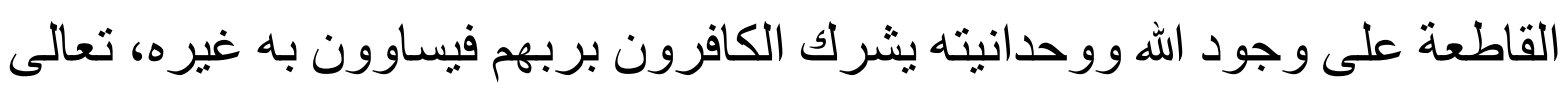
الله عن ذللك، ففي ذلك تعجيب من فعلهم وتوبيخ لهم قال ابن عطية: (الآية دالة

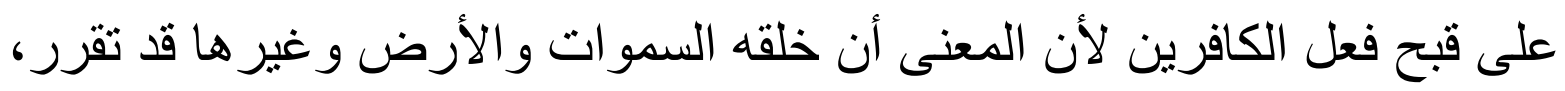

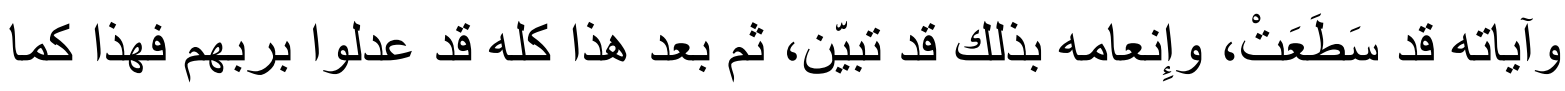

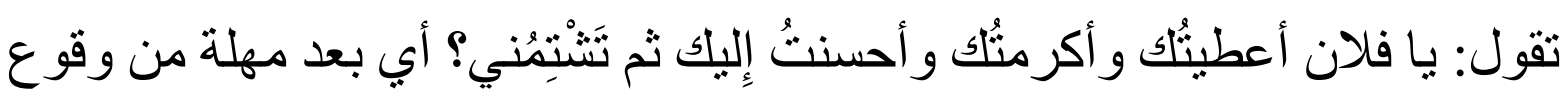

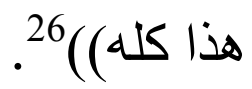

2. عرض كلام البيضاوي في ((أنوار التنزيل وأسرار التأويل)) قال البيضاوي: (100)

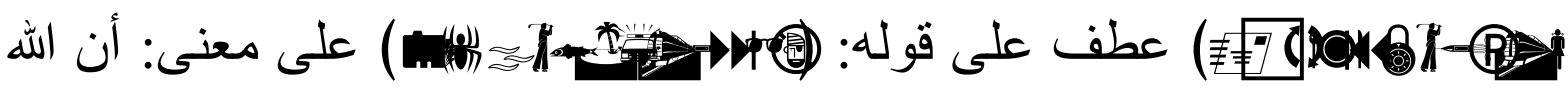

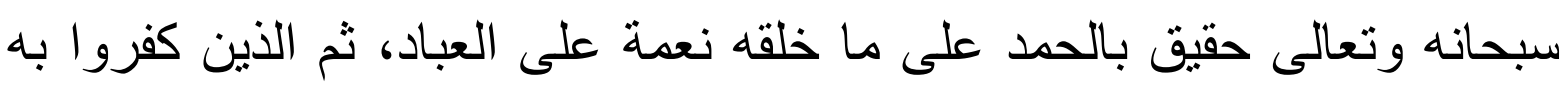

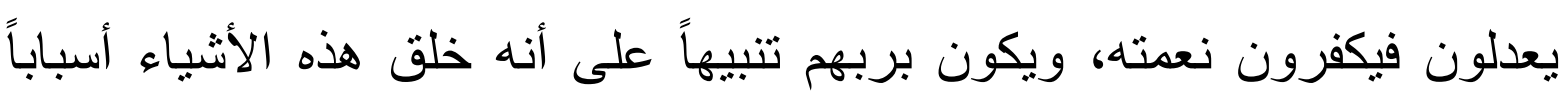

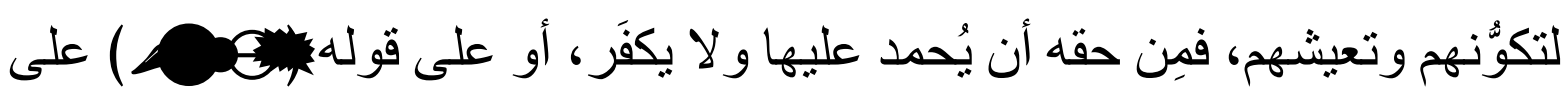

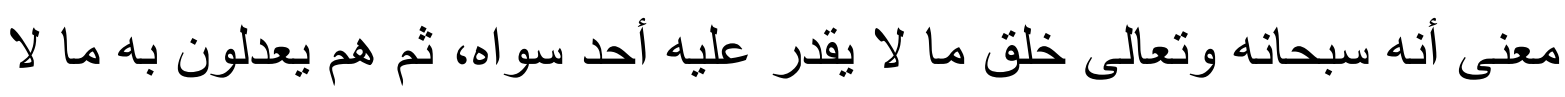

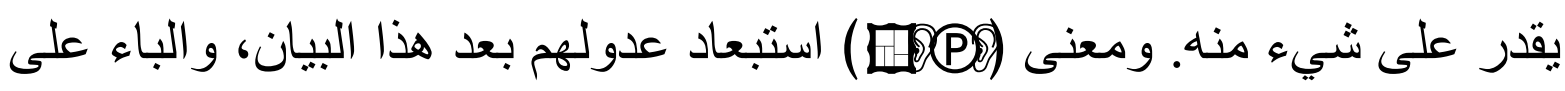

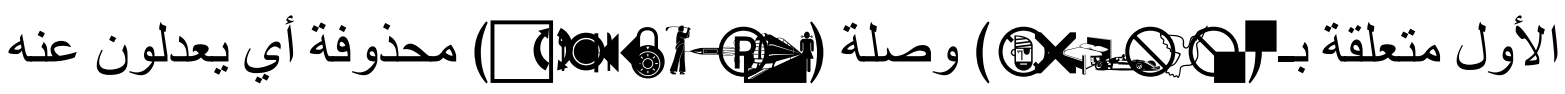

25 ابن جزيّ ((التسهيل لعلوم التنزيل)) تفسير سورة الأنعام، الآية :1، 206/1, دار الكتب العلمية، بيروت، ط،1، 1415هـ 1995 26 ابن عطية ((المحرر الوجيز)) تفسير سورة الأنعام، الآية :1، 266/2، دار الكتب العلمية، بيروت، ط، 1، 1422هـــ 


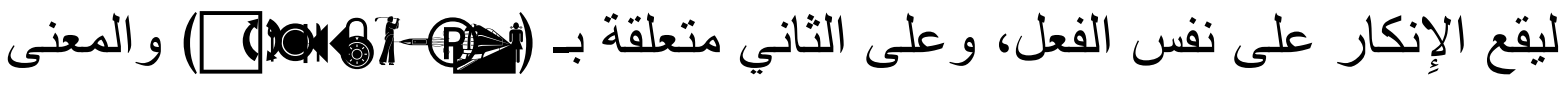

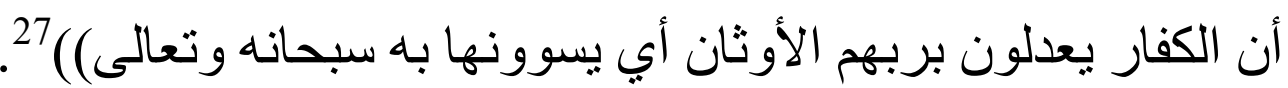

3. 3. 3قيب السيوطي عليه.

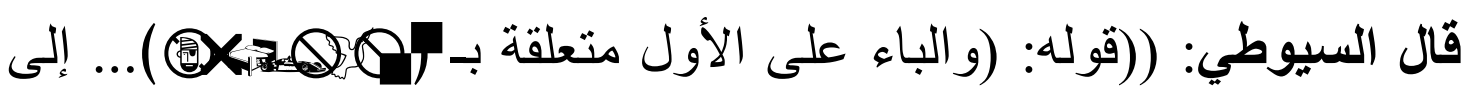
آخره) قال الثيخ سعد الدين: هذا تخصيص من غير مخصص لنتأتي التقديرين على الأى

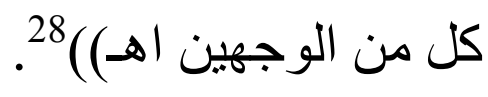

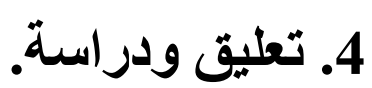

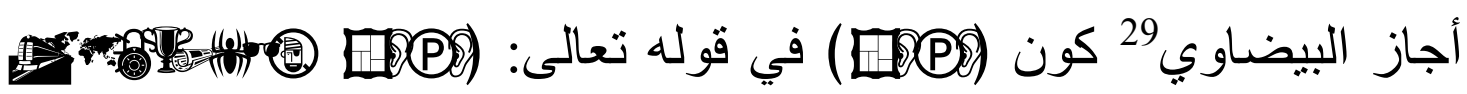

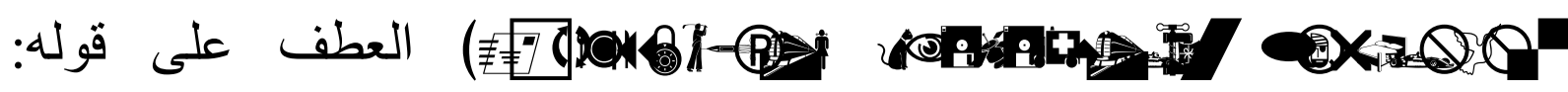

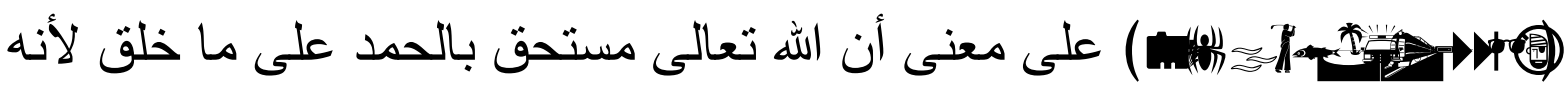

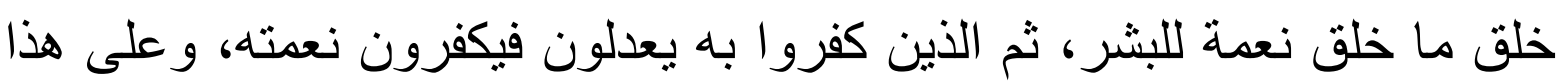

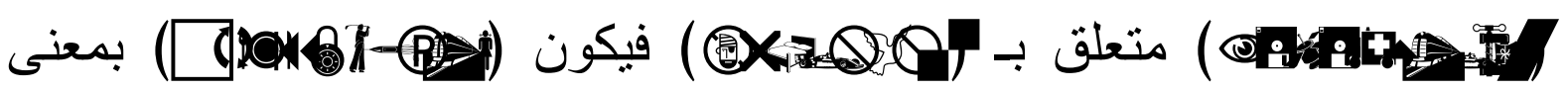

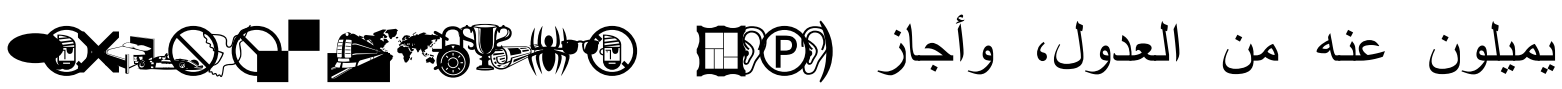

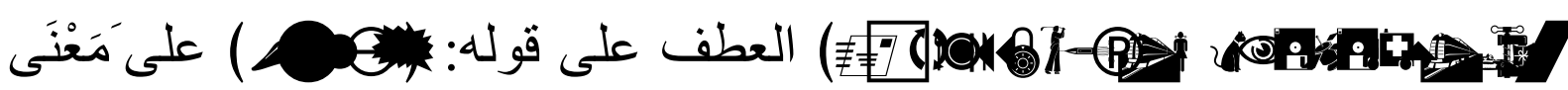

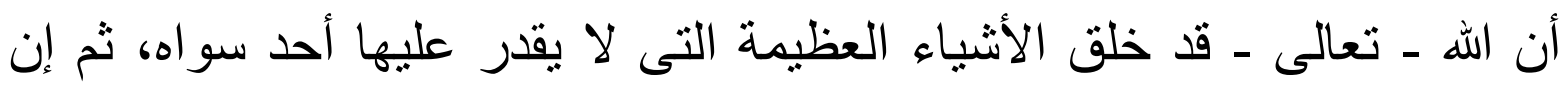

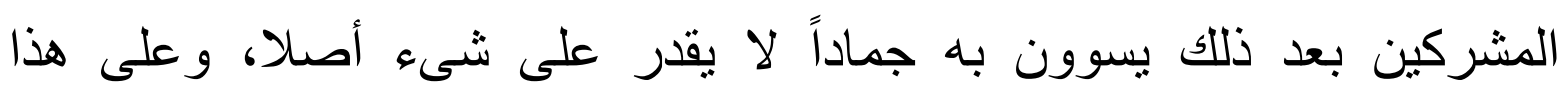

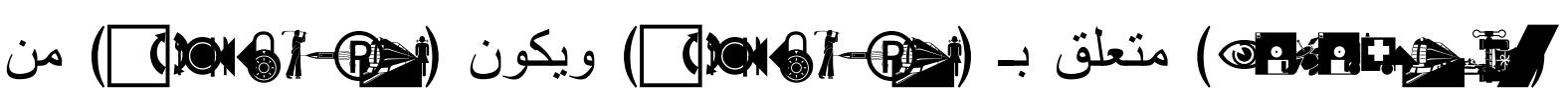
العدل وهو التسوية بين الثيائين، أي: ثم الذين كفروا يسوّون بربهر غيره من

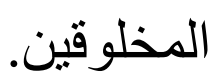

27 البيضاوي ((أنوار التنزيل وأسرار الثأويل)) تفسير سورة الأنعام الآية :1، 294/1، دار صادر، بيروت، ط، 1، 1422هـ 2001 2001.

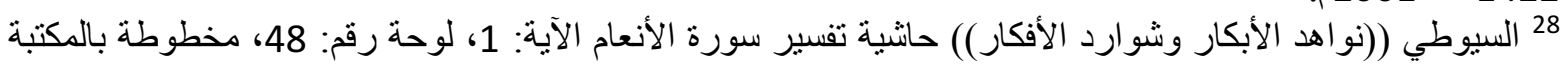

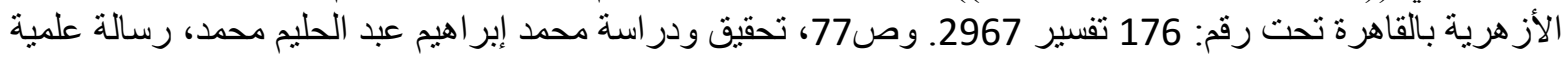

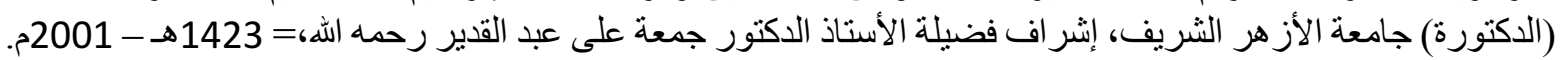
وتحقيق ودر اسة: أحمد بن عبد الله بن علي الدروبي، رسالة علمية (الدكتورة) جامعة أم القرى، إنشر اف: فضيلة الدكتور،

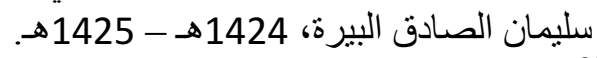
29 وسبقه إليه الزمخشري في (الكثاف)) تفسير سورة الأنعام، الآية: 1424. 321/2. 
و وقّب عليه السيوطي نقلا عن شيخ سعد الدين أن التوجيه على الأول (GPO) العطف على (م)

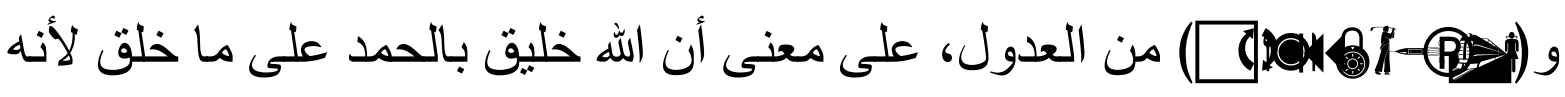

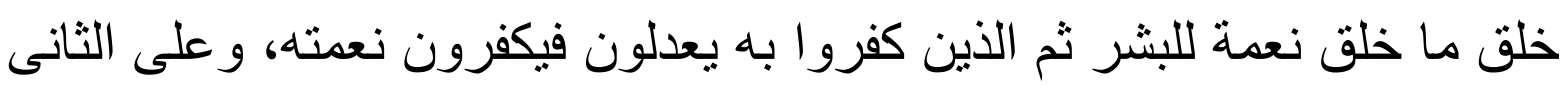

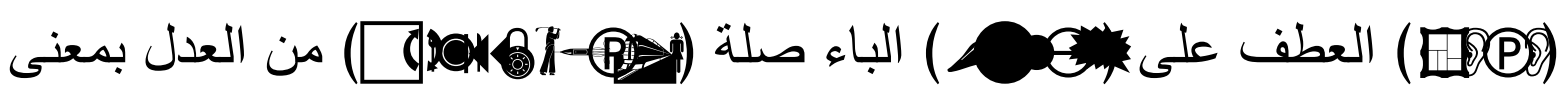

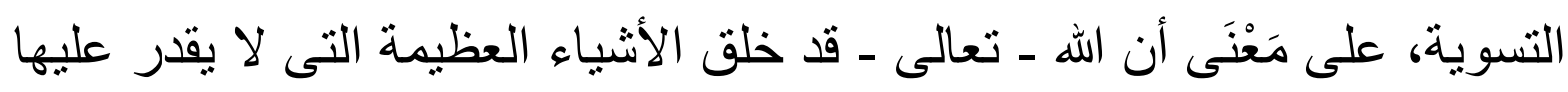

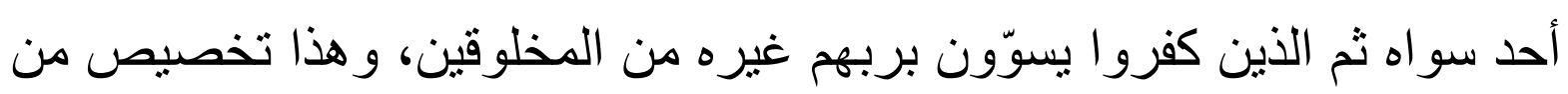

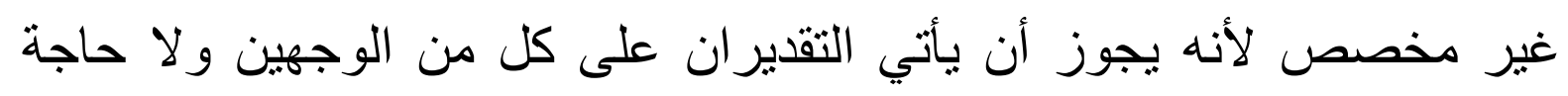

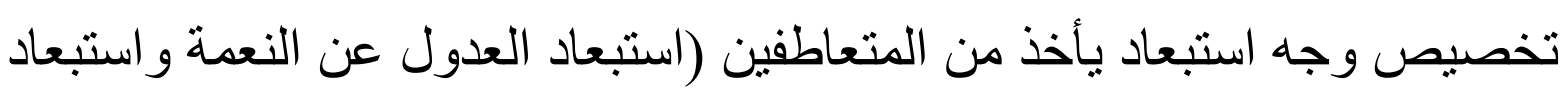

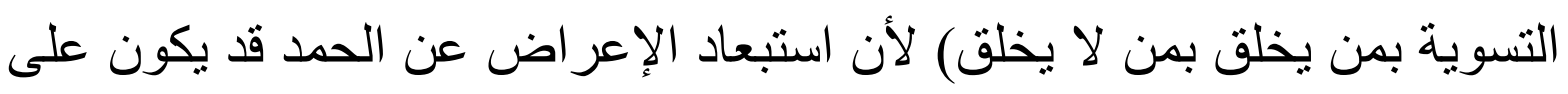

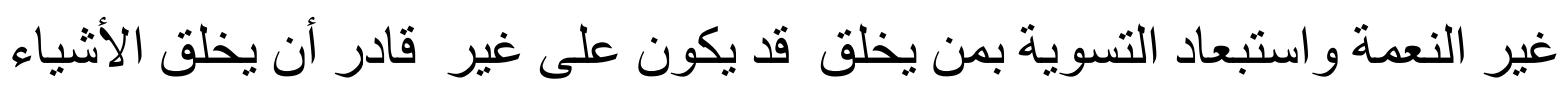

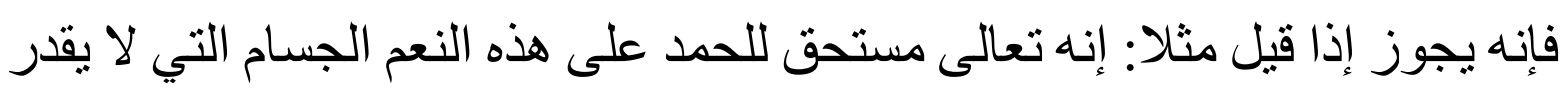

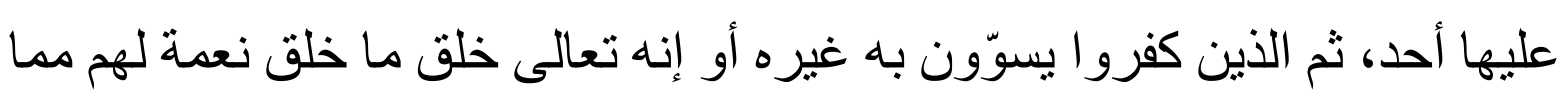
لا يقدر عليه أحد، ثم هم يعدلون عنه و لا يحمدونه.

وفي مثل هذه الحالة بيّن بعض المحققين وجه التخصيص في كل من الوجهين

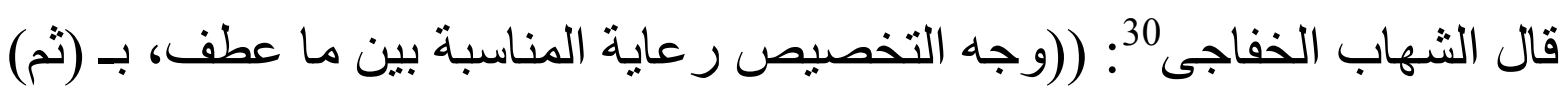

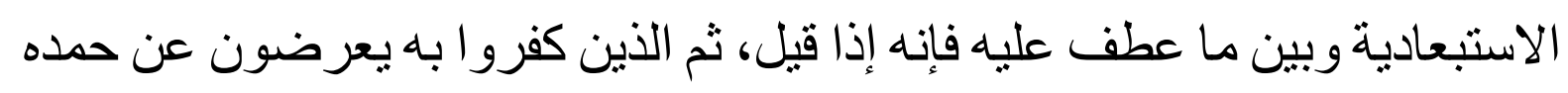

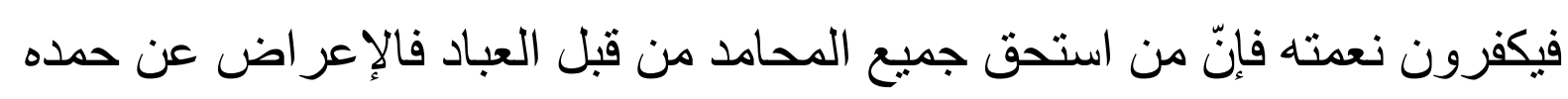

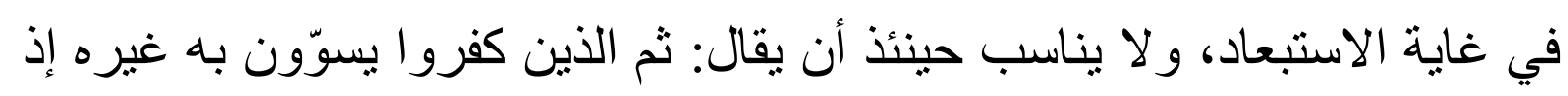

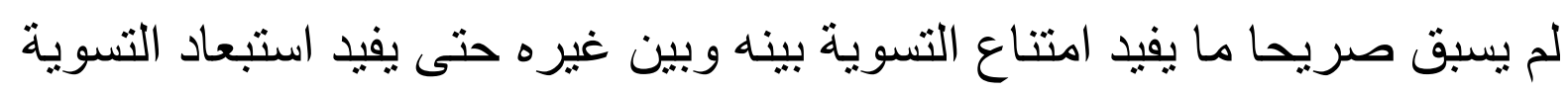

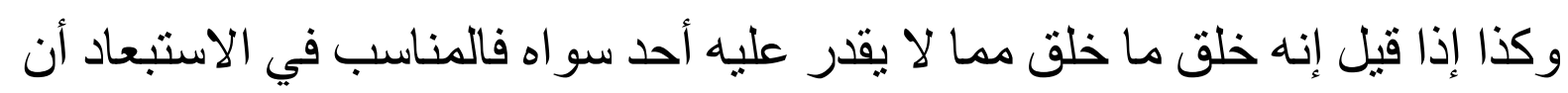

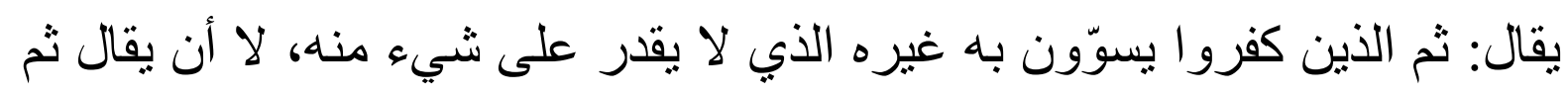

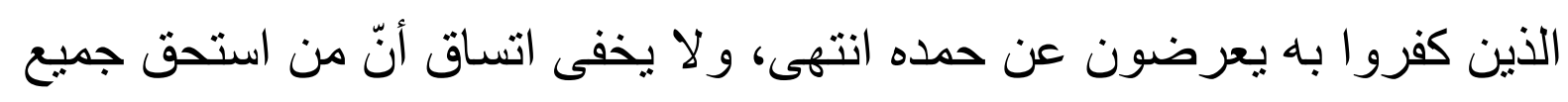

30 هو أحمد بن محمد بن عمر، شهاب الدين الخفاجي المصري، لله مصنفات كثيرة من أبرز ها: حاثشية على تفسير البيضاوي

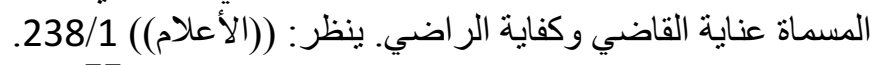


المحامد لإنعامه بالنعم الجسام لا يناسبه أن تكفرو ا نعمته، ومن خلق هذه المخلوقات العظام لا يسوي به غيره)(31).

وتلاه الآلوسي مؤيداً ما قاله الثهاب الخفاجي: ((بأن وجه تخصيص كل بما خصص به اتساق نظم الآية حينئذ وظهور شدة المناسبة بين ما عطف بـ (ثم) (ثون الاستبعادية وبين ما عطف عليه ... إلى أن قال: وقال بعض المحققين: إذا كان

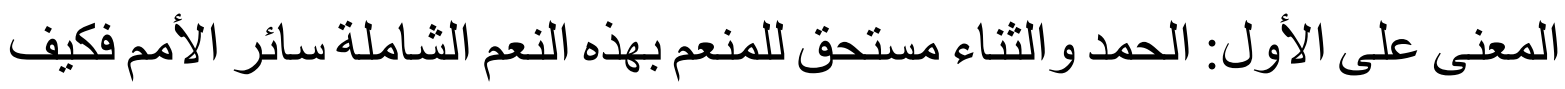
يتأتى من الكفرة والمشركين المستغرقين في بحار إحسانه العدول عنه، و على الإونى الثاني: المعروف بالقدرة على إيجاد هذه المخلوقات العظام التي دخل فيها كل ما ولان

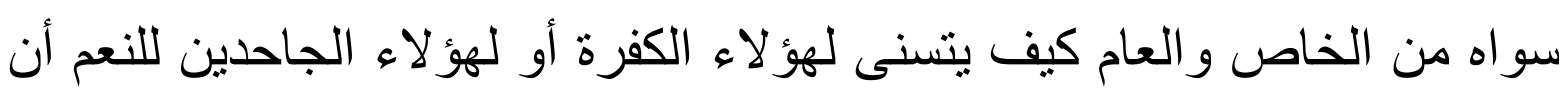
يسووا به غيره وهم في قبضته، فوجه التخصيص في الأول: أنه لا يخفى استبعاد انصر اف العبد عن سيده وولى نعمته إلى سو اه بخلاف التسوية فإن المنعم قد يساويه غيره ممن يحسن إلى غيره، وفي الثاني: أن استبعاد التسوية عليه مما لا يكاد يتصور بخلاف العدول عنه فإنه قد بتصور لجهل العادل بحقه وما يليق بحقه فإن العدول لا ينافي عدم المعرفة بخلاف التسوية فإنه لا يسوي بين شيئين لا يعرفها

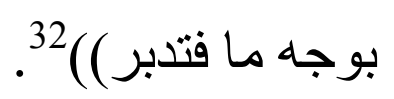

ومن هنا يتبيّن وجه التخصيص كل بما خصص به على الأول لأن الحمد بازئ日)

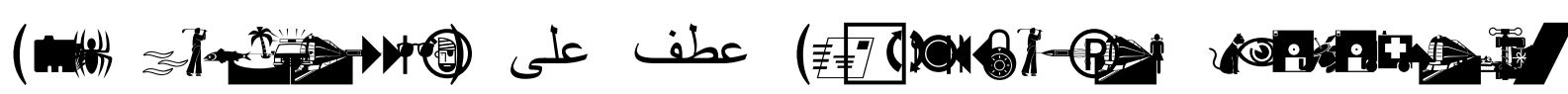

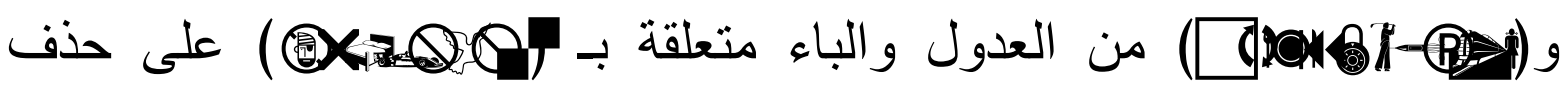
المضاف أى كفروا بنعمة ربهم، وعلى الثانى لأن الثرك بمن يخلق إنما يكون بالتسو

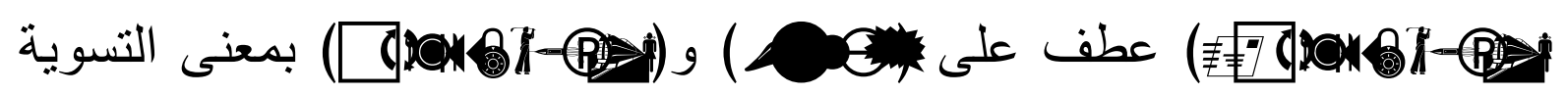

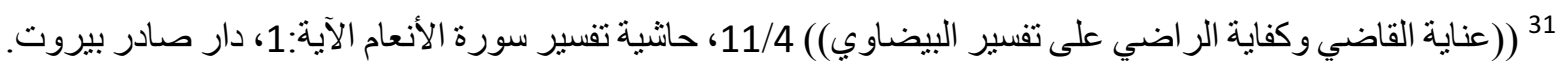

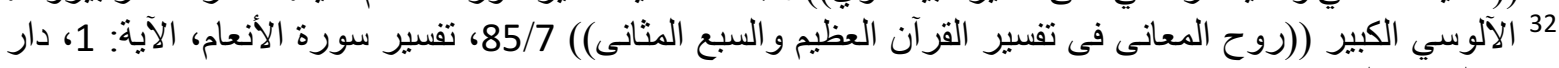


و الباء متعلقة به و على الوجه الأخير دل عليه القرآن كقوله تعالى عن الكفار الذين

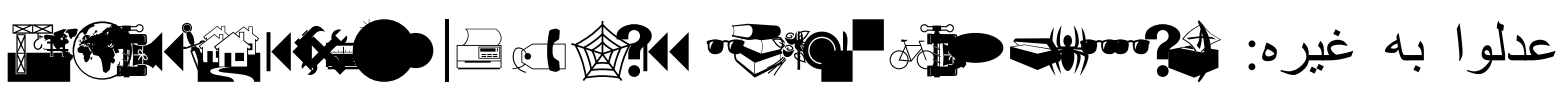

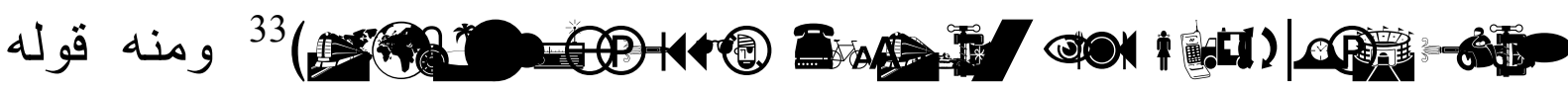

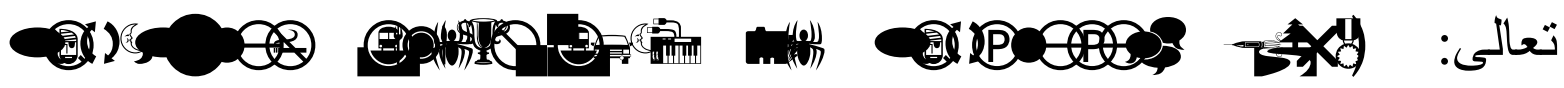
庙XPIP :

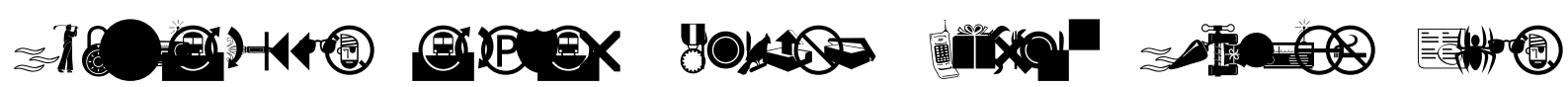

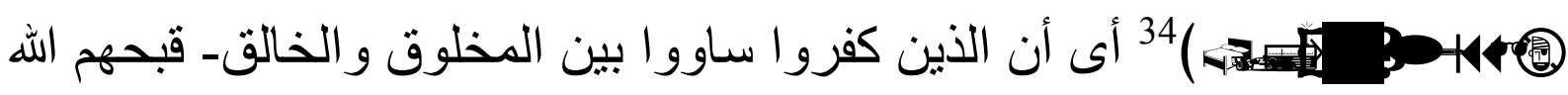
في هذه الآية. و إلى الوجهين ينظر معنى الحديث (وعن التبي (ع) يقول الله تعالى

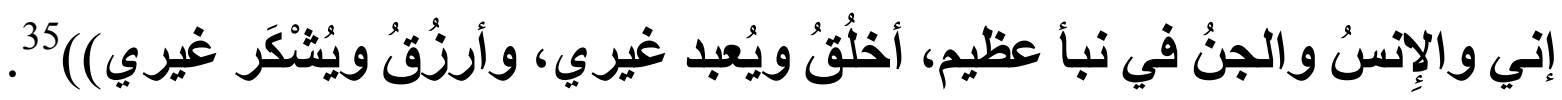
وقال الطيبى: ((إن الكفر يصح أن يحمل على معنى الثرك تارة و على كفران

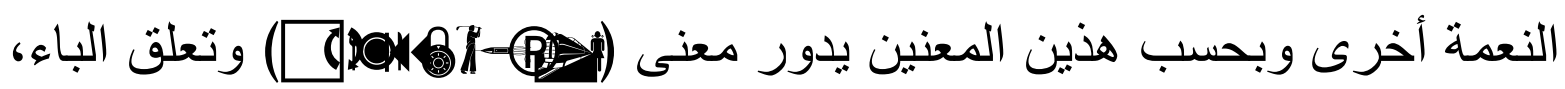

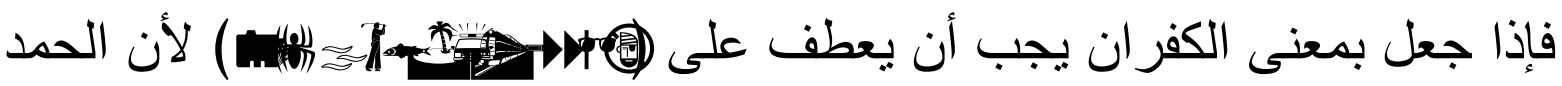

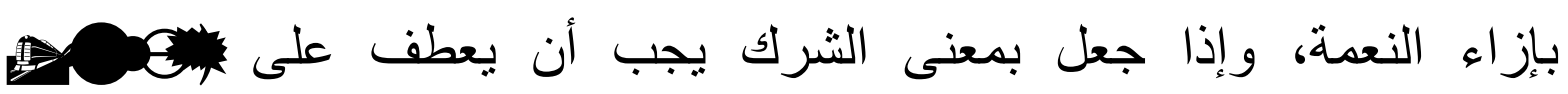

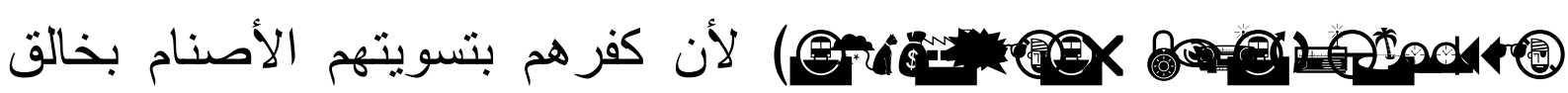

$$
\text { السموات و الأرض)(36. }
$$

وقال المنتجب حسين الهمداني: (و عدل هنا يحتمل أن يكون متعديا و المفعول محذوف بمعنى يعدلون بـه غيره مما لا يقدر على خلق شيئ و لا إنشائه أي بسوونه

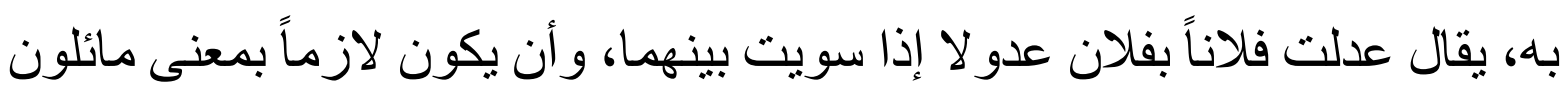

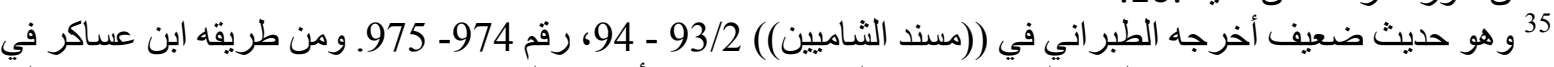

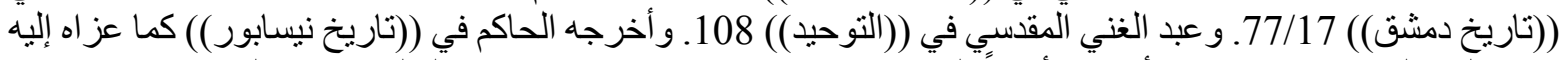

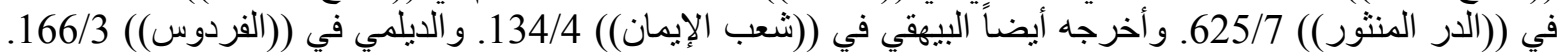

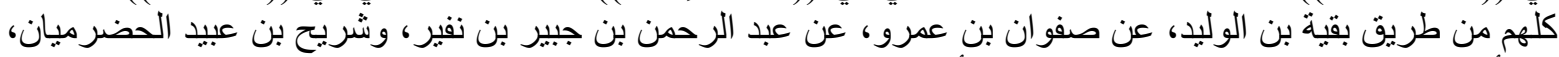

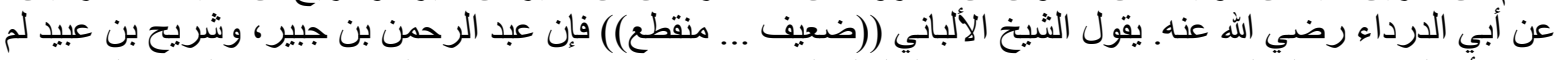

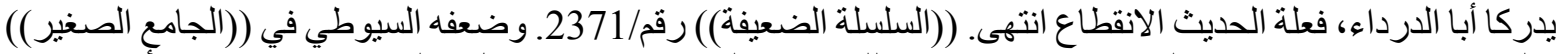

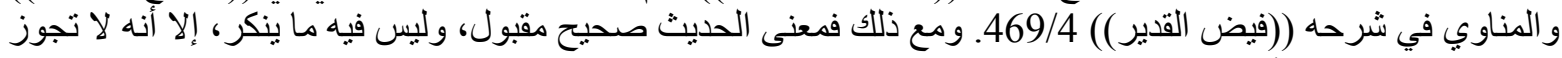

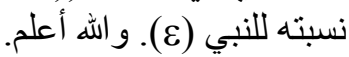

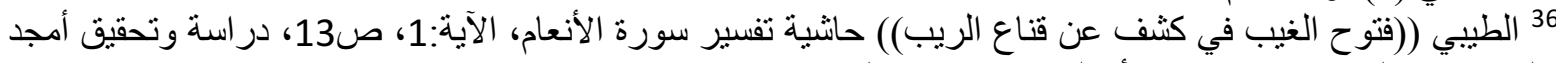

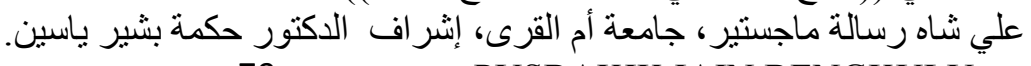


عنه إلى غيره من قولهم: عدل عن الطريق إذا مال عنها وفي التنزيل

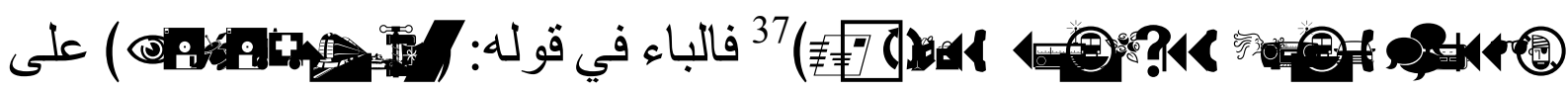

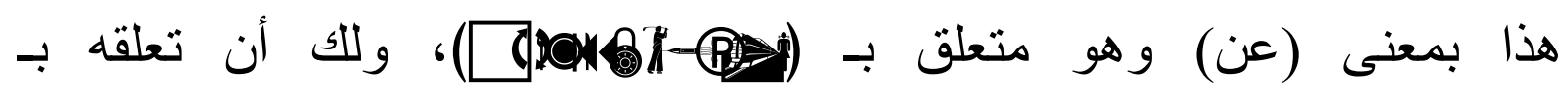

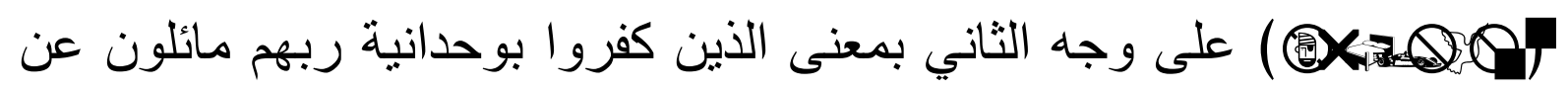
الحق) ( الحق)

نخّلص مما سبق إلى أن ما ذهب إليه البيضاوي من توجيه جواز عطف (四PO)

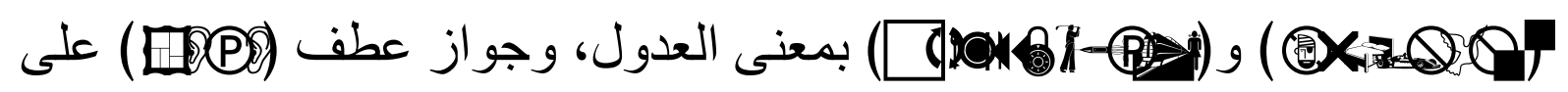

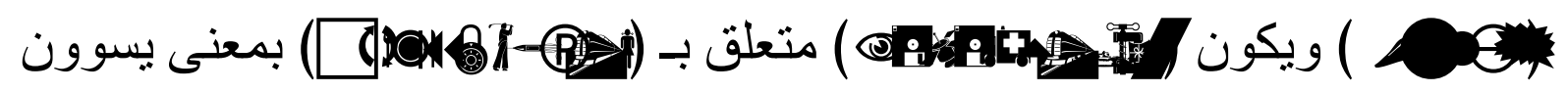

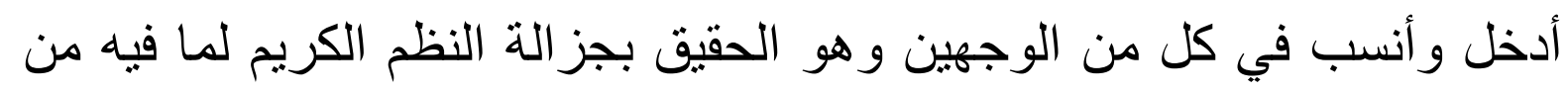

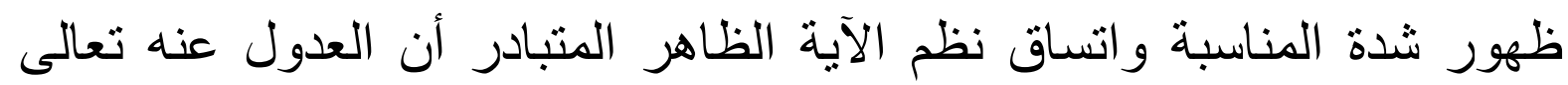
و الاعر اض عن حمده سبحانه في غاية الاستبعاد فيناسب أن يقال: ثم الذين كفروا بربهم يعدلون عنه فلا يحمدونه ورلا يتلفتون لفتة ولا يناسب أن يقال: إنهم يسوون

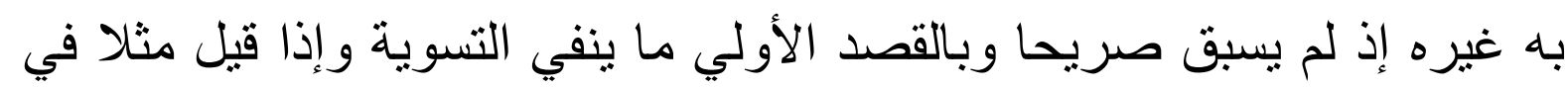

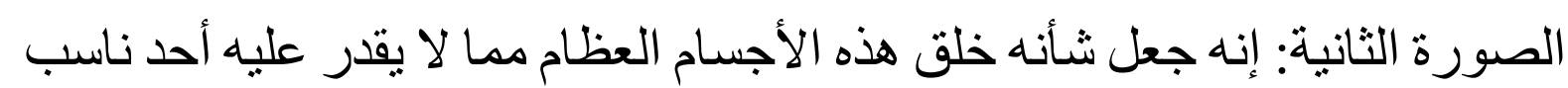
في الاستبعاد أن يقال: ثم الذين كفروا يسوون به ما لا يقدر على شيء لانه أنهم لا لانه

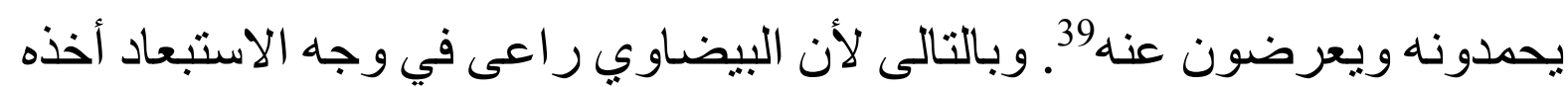

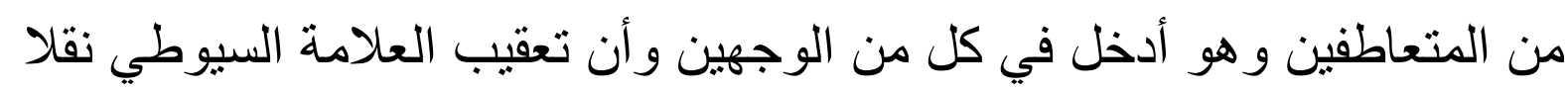

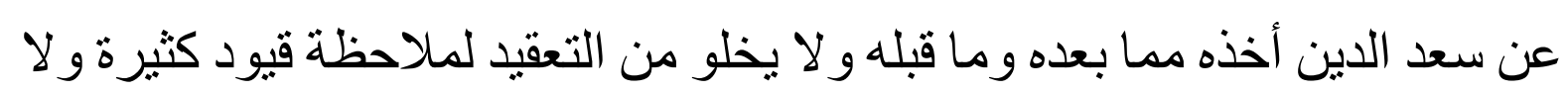

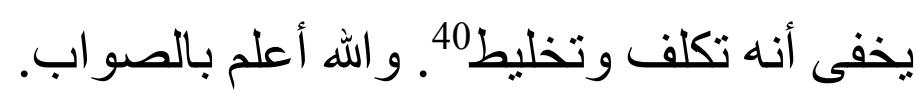

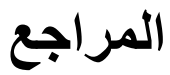


أحكام القرآن: أبو بكر أحمد بن علي الرازي الجصاص (ت 370هـ). تحقيق القيق

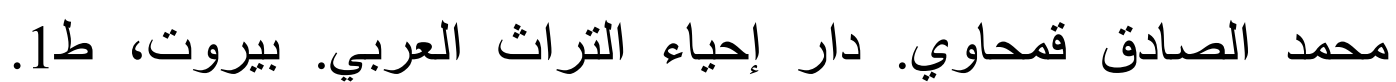

$$
\text { 1412 هـ =ـ 1992م. }
$$

أحكام القرآن: أبو بكر محمد بن عبد الله بن العربي (ت 543هـ). تحقيق محمد

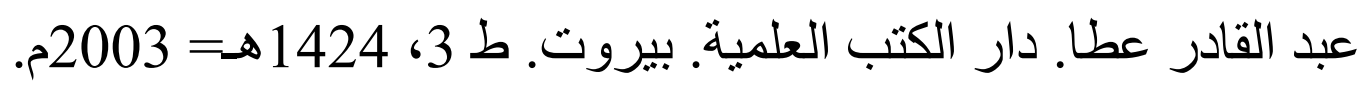
أحكام القرآن: الكيا الهر اسي (ت504هـ). ضبط وتصحيح جماعة من العلماء. دار الكتب العلمية. بيروت. ط1، 1403 هـ= 1983م. 1983. الأساس في التفسير: سعيد حوّى. دار السلام. ط1، 1405 هـ=1985م. إرشاد العقل السليم إلى مز ايا القرآن الكريم: أبو السعود محمد بن محمد العمادي (ت 982 هـ). تحقيق الثيخ محمد صبحي حسن حلاق. دار الفكر بيروت.

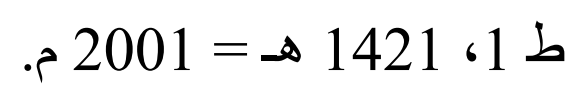

أضواء البيان في إيضاح القرآن بالقر آن: محمد الأمين بن محمد المختار الجكني

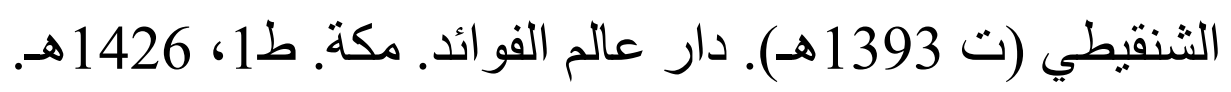

الانتصاف فيما تضمنه الكثاف من الاعتزال: احمد بن محمد ابن المنير الاسكندري المالكي (ت 683هـ). مكتبة ومطبعة مصطفى البابي الحلبي.

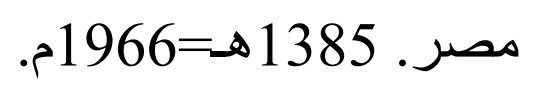

أنوار التنزيل و أسرار التأويل المعروف بـ (تفسير البيضاوي): ناصر الدين أبي

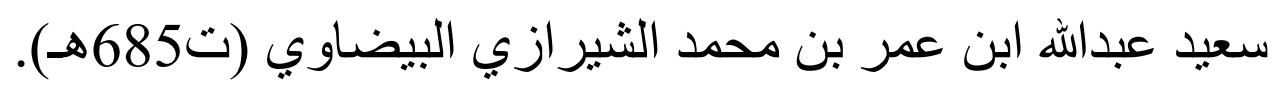
(أ) تقديم: محمود عبد القادر الأرناؤوط. دارصادر. بيروت. ط1، 2001م. (ب) تحقيق: الثيخ محمد صبحي حسن حلاق ومحمد أحمد الأطرش، دار الرشيد

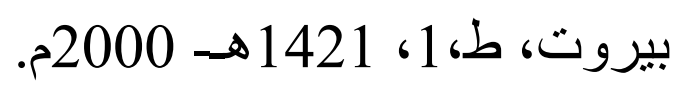


بحر العلوم: أبو الليث السمرقندي (ت375هـ). تحقيق وتعليق الثيخ عادل احمد،

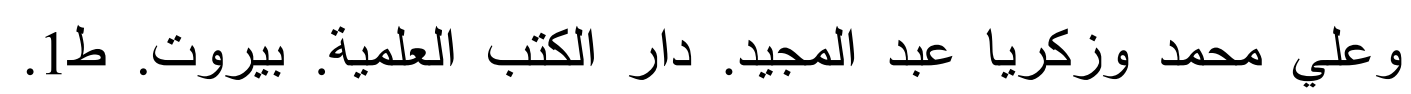

$$
1413 \text { هـ= 1993م. محمد }
$$

البحر المحيط: محمد بن يوسف الثهير بأبي حيان الأندلسي (ت745هـ). در اسة وتحقيق وتعليق الثيخ عادل احمد، و علي محمد. دار الكتب العلمية. لبنان.

$$
\text { بيروت. ط1، 1413 } 14 \text { هـ= 1993م. }
$$

بدائع التفسير: ابن القيم. جمع وتخريج أحاديثه: يسري السيد محمد. دار ابن

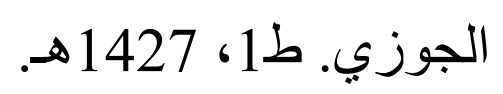

تأويل مشكل القرآن: أبو محمد عبد الله بن مسلم بن قتيبة الدينوري (ت276هـ). شرح الأستاذ السيد أحمد صقر. دار التراث. القاهرة. ط2، 1393هـ 1973م

التبيان في تفسير القرآن: أبو جعفر محمد بن الحسن الطوسي (ت460هـ). تحقيق أحمد حبيب قصير العاملي. دار إحياء التراث العربي. بيروت.

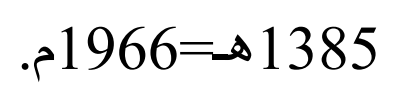

التحرير والتنوير: الطاهر بن عاثور (ت1393هـ) الدار التونسية للنشر. 1984م.

التسهيل لعلوم التنزيل: ابن جزيّ (ت 741هـ). ضبط وتصحيح محمد سالم هاثم.

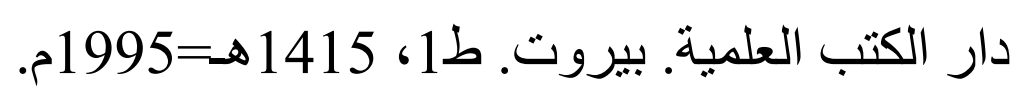

تفسير آيات الأحكام: محمد علي السايس و آخرون. اعتنى به محمد فاضلى. دار

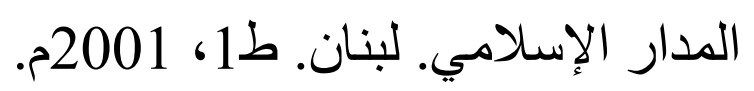


تفسير الإمام الثافعي: أبو عبد الله محمد بن إدريس المطّلبي القرشي (ت204هـ). جمع وتحقيق ودر اسة الدكتور أحمد بن مصطفى الفران. دار التدمرية.

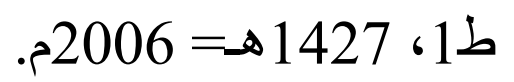

تفسير ابن عرفة: أبو عبد الله محمد بن محمد بن عرفة الورغمي (ت 803هـ). تحقيق جلال الأسيوطي. دار الكتب العلمية. ط1، 2008م.

تفسير الإمام مجاهد بن جبر : مجاهد بن جبر ( ت102 هـ). تحقيق: محمد عبد السلام أبو النيل. دار الفكر الإسلامي الحديثة. ط1، 1410هـ=1989م. 